\title{
Effect of Plant Density on Yield Components and Yield of Faba Bean (Vicia Faba L.) Varieties at Wolaita Sodo, Southern Ethiopia
}

\author{
Wondimu Tamrat ${ }^{1} \quad$ Gobeze Loha $^{2} \quad$ Abera Habte $^{2}$ \\ 1.Agricultural Technical Vocational and Educational Training College, Wolaita Sodo, Ethiopia \\ 2.Wolaita Sodo University, Department of Plant Sciences, Sodo, Ethiopia
}

\begin{abstract}
Faba bean is one of the most popular pulse crops with manifold merits in the economy of the farming communities in the highlands and semi-highlands of Ethiopia. On the other hand, crop yield is functions of different growth and management factors of which optimum plant density is one of the paramount important. Basically, optimum plant density varies with genotypes, ecology, time of planting, production objective, cultural practices, water availability, and nutrients status of the soil. In this context, a field experiment was conducted during 2016 main cropping season at Wolaita Sodo Agricultural Technical Vocational Education and Training College farm in southern Ethiopia with objective of evaluating the effect of plant densities on performance of faba bean varieties. Treatments consisted in three faba bean varieties (Hachalu, Moti and Tumisa) and six level of plant densities $(166,666,222,222,250,000$, $333,333,500,000$ and 666,666 plants/ha) were combined in factorial and laid out in a randomized complete design (RCBD) with three replications. The longest days to flowering and physiological maturity were recorded for variety Tumisa at plant density of 166666 plant/ha and both parameters were shortest for variety Moti at plant density of 666666 plants/ha. The tallest plant height was obtained from the highest plant density and the shortest plants from the lowest plant density. The highest number of pods per plant, seeds per pod and HSW were recorded at plant density of 166666 plants/ha and all parameters were lowest at the highest plant density. Grain yield increased for all varieties with increasing plant densities up to 250000 plants/ha and then declined for further increase in plant density above it with the highest grain yield was recorded for variety Tumisa at plant density of 250000 plants/ha followed by variety Moti at the same plant density. This finding revealed that all the varieties had the highest grain yield at plant density of 250000 plants/ha where the variety Tumisa out yielded and followed by variety Moti. Varieties Tumisa and Moti at plant density 250000 or 222222 plants/ha could the best options for faba bean production.
\end{abstract}

Keywords: faba bean, grain yield, yield components, density, varieties

DOI: $10.7176 / \mathrm{JNSR} / 9-5-07$

Publication date:March $31^{\text {st }} 2019$

\section{Introduction}

Faba bean (Vicia faba L.) is a legume crop belonging to Fabaceae family has a multi-use. It is the fourth most important pulse crop in the world with total average annual production of 4.316.371 tons (Anon, 2010). Major producers of faba bean in the world are China $(1.65 \mathrm{Mt})$, Ethiopia $(0.61 \mathrm{Mt})$, France $(0.44 \mathrm{Mt})$, Egypt $(0.29 \mathrm{Mt})$ and Australia (0.19 Mt) (FAOSTAT, 2009; Sitou and Mywish, 2011). Faba bean is widely cultivated and consumed as a source of protein both in human and animal nutrition, either fresh or dried. It contains a large amount of protein, carbohydrate, B-group vitamins and minerals where its protein content is $29.57-31.83 \%$, carbohydrate $52.96-54.60 \%$, ash $3.37-3.47 \%$, fat $0.81-1.24 \%$ and fiber $10.88-11.96 \%$ depending on varieties (Sarah et al., 2009).

Ethiopia is one of the largest faba bean producing countries in the world next to China and accounts for about $12 \%$ of the world area and production (Mussa and Gemechu, 2006). Thus, the country is considered to be secondary center of diversity and one of the nine major agro-geographical production regions of the crop (Asfaw et al., 1994; Hailu et al., 2014). Faba bean is cultivated as a field crop at highlands in between the altitudes of 1800 and $3000 \mathrm{~m}$ above sea level and mainly grown under rain-fed conditions (Asfaw, 1985). It the most important cool-season food legume crop in Ethiopia in terms of area coverage, production, foreign exchange earnings, protein source, soil amelioration and cropping system (Tafere et al., 2012) and reduces poverty by 3\% (Getachew and Rezene , 2006; ICARDA, 2008).

Plant density is directly correlated with growth and yield parameters of faba bean. Indeed, growth and yield parameters of faba bean like plant height, number of branches, number of pods, pods yield, number of seeds, seed yield, hundred seed weight, biological yield and the overall yield of the crop can be affected considerably (Bakry et al., 2011; Malekmelki et al., 2012; Yucel, 2013, Derogar et al., 2014). Higher plant density above optimum has a significant effect on growth, yield components and yield of most pulse crops including faba bean (Mokhtar, 2001). High plant density may lead to certain morphological modifications on the growth and development of faba bean crop such as increase in plant height, reduction in branching, reduction in number of pods per plant, alteration 
in leaf orientation (Yucel, 2013; Derogar and Mojaddam, 2014). At higher plant densities faba bean plants develop weak stems liable to various climatic and biotic factors that can affect the overall performance of the crop (ICARDA, 2008). Different researchers reported that at higher plant densities intensify interplant competition for growth factors such as sunlight, moisture, air and essential nutrients in the soil (Yucel, 2013, Dergar et al., 2014; Tekle et al., 2015; Wakweya and Meleta, 2016). Moreover, higher plant densities exert significant influence on individual plant morphology of faba bean crop (Khalil et al., 2010; Yucel, 2013). Thus, determining optimum plant density is one of a pre-requisite to increase production and productivity in faba bean (Bakry et al., 2011; Biswas et al., 2012; Wakweya and Meleta, 2016). Hence, this study was initiated with objective to determine the optimum plant density for faba bean varieties.

\section{Materials and methods}

\subsection{Experimental Site}

Field experiment was conducted during 2016/17 main cropping season at Wolaita Sodo Agricultural Technical Vocational Education and Training (ATVET) College demonstration field in Southern Ethiopia. An approximate geographical coordinates of the site is $6^{\circ} 34^{\prime} \mathrm{N}$ latitude and $37^{\circ} 43^{\prime} \mathrm{E}$ longitude having an altitude of $1950 \mathrm{~m} . \mathrm{a} . \mathrm{s} .1$, (Shiferaw, 2008). The area is characterized with a bimodal rainfall distribution pattern with average annual rainfall of $1150 \mathrm{~mm}$. The average minimum and maximum air temperatures are 13.5 and $23{ }^{\circ} \mathrm{C}$, respectively. The soil of the experimental field is of nitosoil and classified as clay loam textural class (Solomon, 2009).

\subsection{Treatments and Experimental Design}

Treatments consisted in three faba bean varieties (Hachalu, Moti and Tumisa) and six level of plant densities $(166,666,222,222,250,000,333,333,500,000$ and 666,666 plants/ha). The respective row and plant spacing to maintain the proposed plant densities were $40 \times 15 \mathrm{~cm}$ for 166,666, $30 \times 15 \mathrm{~cm}$ for 222,222, $40 \times 10 \mathrm{~cm}$ for 250,000, $30 \times 10 \mathrm{~cm}$ for $333,333,40 \times 5 \mathrm{~cm}$ for 500,000 and $30 \times 5 \mathrm{~cm}$ for 666,666 plants/ha. The treatments were combined in factorial and laid out in a randomized complete design (RCBD) with three replications. Each plot was $2.4 \mathrm{~m}$ wide and $2 \mathrm{~m}$ long with total growth area of $4.8 \mathrm{~m}^{2}$. Seeds were hand planted by putting two seeds per hill and thinned after germination to maintain the proposed plant densities per plot. The experimental field was oxen ploughed twice and leveled to get smooth seed bed. Recommended amount of phosphorus was applied in the form of DAP at the rate of $20 \mathrm{~kg} / \mathrm{ha}$ and nitrogen in the form of urea at rate of $16.4 \mathrm{~kg} / \mathrm{ha}$ was applied at planting. All management practices such as cultivation, weeding etc, were done uniformly for all treatments as desired. Disease incidence and insect pests were visually monitored.

\subsection{Data Collection and Measurements}

Plant parameters recorded were days to flowering, physiological maturity, plant height, leaf area index (LAI), number of pods per plant, seeds per pod, hundred seed weight (HSW), biomass, grain yield and harvest index (HI). Days to flowering was recorded as the number of days from planting to $50 \%$ of the plants exhibit flowering per plot. Days to physiological maturity was recorded when $50 \%$ of plants in the plot lose green color of pod. Plant height, LAI, pods per plant and seeds per pod were taken from ten randomly selected plants per plot. Hundred seed weight (HSW) was measured by counting a hundred seeds with a seed counter and weighing it with sensitive balance. Grain yield was harvested from central rows by avoiding border effects and converted to $\mathrm{kg} / \mathrm{ha}$ after adjusting moisture content at $10 \%$. Biomass was determined as the sum of straw weighed and total grain yield. Harvest index (HI) is the ratio of grain to the total biomass and estimated as:

$$
\mathrm{HI}=\frac{\text { Grain yield }}{\text { Biomass yield }}
$$

All collected data were subjected to analysis of variance (ANOVA) using SAS version 9.20 (SAS, 2008) statistical computer software and interpretations were made following the procedure described by Gomez and Gomez (1984). Whenever the effects of the treatments were found to be significant, the means were compared using the Least Significant Differences (LSD) test at 5\% probability level.

\section{Results and discussion}

\subsection{Days to flowering and physiological maturity}

Analysis of variance showed that faba bean varieties were significantly differed with respect to days flowering and physiological maturity (Table 1). Variety Tumisa took the longest days to flowering (54.1) and Iphysiological maturity (115.8) followed by variety Hachalu with mean days to flowering of 53.6 and physiological maturity of 112.3. The shortest days to flowering (45.0) and physiological maturity (108.5) were recorded for variety Moti. The difference of 9.1 days to flowering and 7.3 days to physiological maturity were observed between the longest and shortest days to flowering and physiological maturity. Similarly, plant density had significant effect on days to flowering and physiological maturity (Table 1). Both parameters were shortened as plant density increased. The highest plant density resulted in shortest days to flowering and physiological maturity and vice versa. 
Significant differences were detected due to effect of varieties by plant densities interaction on days to flowering and physiological maturity (Table 1). Generally days flowering and physiological maturity tended to shorten for all varieties as plant densities increased. The longest days to flowering (57.3) was recorded for variety Tumisa at plant density of $166666 \mathrm{plant} /$ ha followed by Hachalu with mean days to flowering of 57.0. The shortest days to flowering (43.0) was seen for variety Moti at plant density of 666666 plants/ha. The difference of 6 days for Hachalu, 3 days for Moti and 5.7 days for Tumisa were recorded between at the lowest and highest plant densities for varieties. This result suggests that variety Moti relatively earlier to flowering as compared Hachalu and Tumisa where as the two varieties response to change in plant densities were relatively similar. The differences in response of varieties to variable plant densities might be attributed to their inheritance variations. Similar findings were reported by Khalil et al. (2011), Tafere et al. (2012), Rehab and El-Rahman (2014) and Tewdros et al. (2015) that faba bean varieties responded differently to variable plant densities for days to flowering. Regarding days to physiological maturity, the longest days to maturity (125.0) was observed for Tumisa at plant density of $166666 \mathrm{plants} / \mathrm{ha}$ followed by the same variety at plant density of 222222 plants/ha with mean days to maturity of 122.3. The shortest days to maturity (101.3) was recorded for variety Moti at plant density of 666666 plants/ha. The difference of 14.7 for variety Hachalu, 12.7 for Moti and 19.4 days were recorded for varieties at the lowest and highest plant densities. This finding probably suggests that days to physiological maturity was more variable for Tumisa and least for Moti while Hachalu is somewhat intermediate in response to plant density. The differences days to maturity of varieties with respect to variable plant densities were likely due to genetic differences among the cultivars. This result is in agreement with the findings of Abdalla et al. (2000), Rehab and El-Rahman (2014) and Ashenafi and Mekuria (2015) reported variations on days of maturity of faba bean varieties in response to different plant densities. However, contradictory finding was reported by Almaz et al. (2016) that at higher plant densities days to physiological maturity delayed for faba bean varieties.

Table 1. Days flowering and physiological maturity as affected by varieties and plant densities

\begin{tabular}{|c|c|c|c|}
\hline Variety & $\begin{array}{l}\text { Plant density } \\
(\mathrm{Ha})\end{array}$ & Days to flowering & Days to maturity \\
\hline \multirow[t]{6}{*}{ Hachalu } & 166666 & $57.0 a$ & $120.0 b c$ \\
\hline & 222222 & $56.3 a$ & $118.3 c$ \\
\hline & 250000 & $55.0 b$ & $113.3 d$ \\
\hline & 333333 & $51.0 d$ & $110.0 d$ \\
\hline & 500000 & $51.3 d$ & $106.6 f$ \\
\hline & 666666 & $51.0 d$ & $105.3 f$ \\
\hline \multirow[t]{6}{*}{ Moti } & 166666 & $46.0 e f$ & $114.0 d$ \\
\hline & 222222 & 45.6ef & $113.0 d$ \\
\hline & 250000 & $45.3 e$ & $110.0 e$ \\
\hline & 333333 & $45.0 f g$ & $106.3 f$ \\
\hline & 500000 & $44.0 h$ & $106.3 f$ \\
\hline & 666666 & $43.0 h$ & $101.3 \mathrm{~g}$ \\
\hline \multirow[t]{8}{*}{ Tumisa } & 166666 & $57.3 a$ & $125.0 a$ \\
\hline & 222222 & $56.3 a$ & $120.0 b c$ \\
\hline & 250000 & $54.6 b$ & $122.3 a b$ \\
\hline & 333333 & $53.0 c$ & $115.0 d$ \\
\hline & 500000 & $51.6 d$ & $106.6 f$ \\
\hline & 666666 & $51.6 d$ & $105.6 f$ \\
\hline & $L S D$ & 1.1 & 2.6 \\
\hline & Hachalu & $53.6 b$ & $112.3 b$ \\
\hline \multirow[t]{5}{*}{ Variety mean } & Moti & $45.0 c$ & $108.5 c$ \\
\hline & Tumisa & $54.1 a$ & $115.8 a$ \\
\hline & $L S D$ & 0.48 & 1.1 \\
\hline & 166666 & $53.6 a$ & $119.7 a$ \\
\hline & 222222 & $52.3 b$ & $116.1 b$ \\
\hline \multirow[t]{6}{*}{ Plant density mean } & 250000 & $52.0 b$ & $116.2 b$ \\
\hline & 333333 & $50.0 c$ & $110.4 c$ \\
\hline & 500000 & $49.0 d$ & $106.5 d$ \\
\hline & 666666 & $48.5 d$ & $104.1 e$ \\
\hline & $L S D$ & 0.68 & 1.55 \\
\hline & $C V(\%)$ & 1.4 & 3.4 \\
\hline
\end{tabular}

Means followed by the different letters within columns are significantly different at $5 \%$ probability level, NS $=$ not significant 


\subsection{Plant height, pods per plant, seeds per pod and hundred seed weight}

Analysis of variance indicated that varieties exhibited significant differences on plant heights, pods per plant, seeds per pod and HSW (Table 2). The tallest pant heights $(130.2 \mathrm{~cm})$ and the highest HSW $(95.78 \mathrm{~g})$ were recorded for variety Tumisa followed by Hachalu with mean plant heights of $129.6 \mathrm{~cm}$ and HSW of $94.28 \mathrm{~g}$. The shortest plant height $(126.8 \mathrm{~cm})$ and lowest HSW $(93.89 \mathrm{~g})$ were seen for variety Moti. The differences in plant height among varieties could be attributed to the difference in their genetic makeup. This result is in agreement with findings of Peksen et al. (2006), Bakry et al. (20110), Yucel (2013) and Abd El-azeem et al. (2014) that there were plant height variations for faba bean cultivars. With respect to number of pods per plant and seeds per pod, the greatest number of pods per plant (17.19) was obtained from variety Hachalu and seeds per pod (3.19) from Tumisa. The least number of pods per plant (13.84) and seeds per pod (3.10) were achieved from variety Moti (Table 2).

Significant differences were detected due to effect of plant densities on plant height, pods per plant, seeds per pod and HSW (Table 2). Generally, plant height tended to increase with increasing plant densities. The tallest plant height $(139.0 \mathrm{~cm})$ was obtained from the highest plant density followed by plant density of 500000 plants/ha with mean plant height of $133.1 \mathrm{~cm}$. The shortest plant height $(121.1 \mathrm{~cm})$ was achieved from plant density of 166666 plants/ha. Higher plant densities resulted in taller plant heights whereas lower plant densities resulted in shorter plants. The tallest plant height at a high plant density was likely due to the elongation of internodes ('etiolation' as a result of insufficient radiation penetration, over shading and self shading). When plants are placed in close proximity of each other as a result of increased plant density, the internode length and stems become elongated due to a phototropism reaction of plants in response to light stimulus (Mason et al., 1974; Leopold and Kreidemann, 1975; Park et al., 1989). This was also confirmed by Ogunlella et al. (2005) and Amanullah et al. (2010) indicated that plants were taller with increased plant density in reaction to an enhanced competition among plants for light. Conversely, varieties by plant densities interactions did not have significant effect on plant height. On the other hand, number of pods per plant, seeds per pod and HSW showed the tendency of declining as plant densities increased (Table 2). The highest number of pods per plant (21.28), seeds per pod (3.51) and HSW (98.22 g) were receded at plant density of 166666 plants/ha followed by plant density of 222222 plants/ha with mean number of pods per plant 17.23, seeds per pod of 3.22 and HSW of $97.22 \mathrm{~g}$. All parameters were lowest at the highest plant density. In line with this, varieties by plant densities interactions resulted in significant differences on number of pods per plant (Table 2). Number of pods per plant showed tendency of decreasing for all varieties as plant densities increased. The greatest number of pods per plant (24.46) was observed for variety Tumisa at plant density of 166 666 plants/ha followed by variety Hachalu at the same plant density with mean number of pods per plant of 21.38. The lowest number of pods per plant (9.50) was seen for variety Moti at plant density of 666666 plants/ha. The result is in accordance with the works of Dahmardeh et al. (2010), Osman et al. (2010), Bakry et al. (2011) and Tekle et al. (2015) indicated that faba bean varieties differ in yielding number of pods per plant. Moreover, Shad et al. (2010), Derogar and Mojaddam (2014) and and Almaz et al. (2016) showed that increasing plant densities may lead to a decrease in the number of pods per plant in faba bean is due to a reduction in the number of pod bearing branches per plant. Conversely, varieties by plant densities interactions did not result in significant differences on plant height, seeds per pod and HSW.

Table 2. Plant height, pods per plant, seeds per pod and HSW as affected by varieties and plant densities

\begin{tabular}{|c|c|c|c|c|c|}
\hline Variety & $\begin{array}{l}\text { Plant density } \\
(\mathrm{Ha})\end{array}$ & $\begin{array}{l}\text { Plant height } \\
(\mathrm{cm})\end{array}$ & Pods/plant & Seeds/pod & $\begin{array}{l}H S W \\
(g)\end{array}$ \\
\hline \multirow[t]{6}{*}{ Hachalu } & 166666 & 120.6 & $21.38 b$ & 3.19 & 97.33 \\
\hline & 222222 & 128.1 & $20.00 b c$ & 3.00 & 96.66 \\
\hline & 250000 & 125.5 & $16.96 \mathrm{~d}-f$ & 2.96 & 96.00 \\
\hline & 333333 & 132.9 & $16.50 d-f$ & 2.62 & 91.66 \\
\hline & 500000 & 130.2 & $15.13 \mathrm{fg}$ & 2.71 & 93.66 \\
\hline & 666666 & 140.3 & $13.17 \mathrm{gh}$ & 2.62 & 90.33 \\
\hline \multirow[t]{6}{*}{ Moti } & 166666 & 120.8 & $18.00 c-e$ & 3.50 & 97.33 \\
\hline & 222222 & 121.2 & $16.09 e f$ & 3.21 & 96.66 \\
\hline & 250000 & 122.1 & $14.54 f-h$ & 3.25 & 95.00 \\
\hline & 333333 & 132.7 & $12.63 g-i$ & 2.92 & 90.66 \\
\hline & 500000 & 127.1 & $12.25 h-j$ & 2.96 & 93.33 \\
\hline & 666666 & 137.1 & $9.50 j$ & 2.75 & 90.33 \\
\hline \multirow[t]{7}{*}{ Tumisa } & 166666 & 121.8 & $24.46 a$ & 3.75 & 100.00 \\
\hline & 222222 & 127.0 & $19.13 b-d$ & 3.46 & 98.33 \\
\hline & 250000 & 133.3 & $16.50 d-f$ & 3.25 & 98.33 \\
\hline & 333333 & 125.6 & $13.21 \mathrm{gh}$ & 2.88 & 92.66 \\
\hline & 500000 & 133.7 & $12.25 h-j$ & 2.96 & 95.33 \\
\hline & 666666 & 139.7 & $10.21 i j$ & 2.83 & 90.00 \\
\hline & $L S D$ & $N S$ & 2.8 & $N S$ & $N S$ \\
\hline
\end{tabular}




\begin{tabular}{llllll}
\hline \multirow{3}{*}{ Variety mean } & Hachalu & $129.6 a$ & $17.19 a$ & $2.87 c$ & $94.28 b$ \\
& Moti & $126.8 b$ & $13.84 c$ & $3.10 b$ & $93.89 b$ \\
& Tumisa & $130.2 a$ & $15.96 b$ & $3.19 a$ & $95.78 a$ \\
& LSD & 1.30 & 1.14 & 0.06 & 1.37 \\
\hline \multirow{5}{*}{ Plant density mean } & 166666 & $121.1 e$ & $21.28 a$ & $3.51 a$ & $98.22 a$ \\
& 222222 & $124.8 d$ & $17.23 b$ & $3.22 b$ & $97.22 a$ \\
& 250000 & $125.0 d$ & $17.01 b$ & $3.15 b$ & $96.44 a$ \\
& 333333 & $130.1 c$ & $14.14 c$ & $2.87 c$ & $94.11 b$ \\
& 500000 & $133.1 b$ & $13.33 c$ & $2.81 c d$ & $91.66 c$ \\
& 666666 & $139.0 a$ & $10.95 d$ & $2.74 d$ & $90.22 c$ \\
& LSD & 1.9 & 1.62 & 0.09 & 1.94 \\
\hline
\end{tabular}

Means followed by the different letters within columns are significantly different at $5 \%$ probability level, $\mathrm{NS}=$ not significant

\subsection{Biomass, grain yield, harvest index and plant lodging}

Analysis of variance revealed that varieties showed significant differences on biomass yield, grain yield, HI (Table 3). The greatest biomass production $(12260 \mathrm{~kg} / \mathrm{ha}$ ) was found from variety Moti followed by variety Hachalu with mean biomass yield of $11970 \mathrm{~kg} / \mathrm{ha}$. The lowest biomass yield $(11710 \mathrm{~kg} / \mathrm{ha})$ was obtained from variety Tumisa. Biomass is a function of numerous interacting environmental and genetic factors and its production is directly related to potential growth and development factors such as solar radiation, water supply, availability of mineral nutrients and crop management practices. Thus, the differences in biomass yield among varieties might be due to the genetic variability on the performance of varieties in response to the growing environment. With respect to grain yield and HI, both parameters were highest for variety Tumisa and followed by Moti. The lowest grain yield $(3559 \mathrm{~kg} / \mathrm{ha}$ ) was obtained from variety Hachalu. Similarly, biomass, grain yield and HI were significantly differed due to effect plant densities (Table 3). Biomass yield as affected by plant density ranged from 10450 to 13820 $\mathrm{kg} / \mathrm{ha}$. The highest biomass yield $(13820 \mathrm{~kg} / \mathrm{ha})$ recorded at plant density of 500000 plants $/$ ha followed by plant density of 333333 plants/ha with mean biomass yield of $13120 \mathrm{~kg} / \mathrm{ha}$. The lowest biomass yield $(10450 \mathrm{~kg} / \mathrm{ha})$ was obtained from plant density of $166666 \mathrm{plants} / \mathrm{ha}$ (Table 3). This illustrated that subjecting plants to high plant density increased the ability of plants for capturing resources which was reflected as evident in their increased biomass production. Bullock et al. (1998) proved that high plant densities (narrow row spacings) made more efficient use of available light and shaded the soil surface to a greater degree during the early part of the growing season while the soil is still moist and therefore, higher plant densities are more effective in producing biomass. Regarding grain yield, it increased with increasing plant density up to 250000 plants/ha and then declined with further increment of plant density above that optimum level. The highest grain yield $(4202 \mathrm{~kg} / \mathrm{ha})$ was achieved from plant density of 250000 plants/ha followed by plant density of 222222 plants/ha with mean grain yield of $4045 \mathrm{~kg} / \mathrm{ha}$. The lowest grain yield ( $3032 \mathrm{~kg} / \mathrm{ha}$ ) was recorded at plant density of $666666 \mathrm{plants} / \mathrm{ha}$. Regarding the $\mathrm{HI}$, it was greatest at the lowest plant density and lowest at the highest plant density.

Analysis of variance revealed that significant differences were detected due to the effect of varieties by plant density interactions on grain yield and HI (Table 3). Generally, grain yield increased for all varieties with increasing plant densities up to 250000 plants/ha and then declined for further increase in plant density above it. The highest grain yield (4330 kg/ha) was recorded for variety Tumisa at plant density of 250000 plants/ha followed by variety Moti at the same plant density with mean grain yield of $4188 \mathrm{~kg} / \mathrm{ha}$. The lowest grain yield (3003 kg/ha) was seen for variety Moti at plant density of 666666 plants/ha. Thus, plant density 250000 plants/ha seems to be optimum for all varieties. Decreasing plant density from 250000 to 222222 plants/ha resulted in yield loss $3.1 \%$ for Halachu, $3.7 \%$ for Moti and $4.8 \%$ for variety Tumisa. In line with this, increasing plant density from 250000 to 333333 plants led to a yield loss $25.9 \%$ for Hachalu, $37.6 \%$ for Moti and $6.3 \%$ for Tumisa. This suggests that varieties were more sensitive to yield reduction for plant densities above the optimum than reduction below the optimum. With respect to HI, all varieties had the highest $\mathrm{HI}$ at the lowest plant density and lowest HI at the highest plant density. This result is in conformity with findings of Gebremeskel et al. (2011), Abdalla et al. (2015) and Ashenafi and Mekuria (2015) reported that HI varies for different faba bean varieties at different plant densities. In line with this, AL-Rifaee et al. (2004), Mahmoud (2014) and Tekle et al. (2015) indicated that low plant density results higher $\mathrm{HI}$ as compared to higher plant densities.

Crop yield is a function of a number of factors and processes such as amount of light intercepted by the canopy, metabolic efficiency of plants and the translocation efficiency of photosynthates from leaves to economic parts. These processes are affected by crop cultivars and plant densities. Differences in plant densities in of this study caused a profound impact on faba bean grain yield by affecting yield and yield components. Plant density exerts a strong influence on faba bean growth and yield as a result of the competitive ability of plants at variable densities (Singh and Chaudhary, 2008). Balanced growth and development of plants need an optimum plant 
density because optimum density enable plants' efficient utilization of available nutrients, soil water and better light interception coupled with other growth factors. Increasing plant density above an optimum level intensifies competition for solar radiation, soil nutrients and soil moisture. Moreover, high plant density can cause lodging, less light penetration in the crop canopy leading reduced photosynthetic efficiency of the plants resulting in drastic yield reduction (Lemerle et al., 2004; Lemerle et al., 2006; and Shad et al., 2010). On the other hand, plant density lower than optimum exhibited lower grain yield per unit area which might attributed to a lower number of plants per unit area. Reduction of plant density below an optimum resulted in a negative impact on grain yield primarily due to underutilization of resources. The same impact was reported by Hashemi- Dezfouli \& Herbert (1992) and Echarte et al. (2000) that plant density below the optimum led to decreased use efficiency of available resources. In contrast, varieties by plant densities interactions did not result in significant differences on biomass yield.

Plant lodging was significantly differed due to interaction effect of varieties by plant densities (Table 3). A variable number of lodged plants were recorded in response of varieties to pant densities. For all varieties the highest plant lodging was observed at the highest plant densities. At plant density above 250000 plants/ha variety Hachalu was more liable to lodging while the remaining two varieties more or less similar with respect to tolerance to lodging at higher plant densities. At higher plant densities ( $P D \geq 250000$ plants/ha) plant lodging might be the result of weak stems and shallow root development due to overcrowding of plants per unit area. The tendency of plant lodging at increased plant density is also associated with a disorganized light profile in dense plant densities according to Sangoi and Salvador (1996). Rajcan \& Swanton (2001) suggested that when plants grow in a dense canopy, they tend to receive a different quality of light radiation, enriched with far red (FR) and impoverished in red $(\mathrm{R})$ radiation where this high $\mathrm{FR} / \mathrm{R}$ ratio triggers many morphological changes in plant architecture, stimulating stem elongation, favouring apical dominance and reducing stem diameter. Such changes make plant stalks more susceptible to stem breakage and root lodging before seeds attain physiological maturity.

\section{Conclusion}

Grain yield is a function of several factors and processes, such as interception of solar radiation, metabolic efficiency of plants, translocation efficiency of photosynthates from leaves to economic parts, sink strength and genetic make-up of the crop. Thus, sustainable production depends on the correct application of production inputs sustaining both the environment and agriculture. The current investigation clearly showed that all the varieties had the highest grain yield at plant density of 250000 plants/ha where the variety Tumisa out yielded and followed by variety Moti. Varieties Tumisa and Moti at plant density 250000 or 222222 plants/ha could the best options for faba bean production.

Table 3. Biomass, grain yield, HI and plant lodging as affected by varieties and plant densities

\begin{tabular}{|c|c|c|c|c|c|}
\hline Variety & $\begin{array}{l}\text { Plant density } \\
(\mathrm{Ha})\end{array}$ & $\begin{array}{l}\text { Biomass } \\
(\mathrm{kg} / \mathrm{ha})\end{array}$ & $\begin{array}{l}\text { Grain yield } \\
(\mathrm{kg} / \mathrm{ha})\end{array}$ & $H I$ & $\begin{array}{l}\text { Plant lodging } \\
(\%)\end{array}$ \\
\hline \multirow[t]{6}{*}{ Hachalu } & 166666 & 12110 & $3888 e f$ & $0.33 a$ & 10.00hi \\
\hline & 222222 & 10410 & $3967 d e$ & $0.30 c d$ & $16.66 \mathrm{~g}$ \\
\hline & 250000 & 13100 & $4088 c$ & $0.29 d-f$ & $18.86 f g$ \\
\hline & 333333 & 10870 & $3246 i$ & $0.27 g h$ & $32.77 b$ \\
\hline & 500000 & 13960 & $3113 j$ & $0.26 f g$ & $33.50 a b$ \\
\hline & 666666 & 11340 & $3055 j k$ & $0.26 f g$ & $35.93 a$ \\
\hline \multirow[t]{6}{*}{ Moti } & 166666 & 12250 & $3368 h$ & $0.34 a$ & $10.83 h i$ \\
\hline & 222222 & 10640 & $4038 c d$ & $0.31 b c$ & $17.92 \mathrm{~g}$ \\
\hline & 250000 & 13390 & $4188 b$ & $0.30 c d$ & $20.55 f$ \\
\hline & 333333 & 11110 & $3043 j k$ & $0.27 \mathrm{gh}$ & $25.69 \mathrm{de}$ \\
\hline & 500000 & 14240 & $3043 j k$ & $0.26 f g$ & $26.46 \mathrm{de}$ \\
\hline & 666666 & 11920 & $3003 k$ & $0.25 i$ & $29.68 c$ \\
\hline \multirow[t]{8}{*}{ Tumisa } & 166666 & 12390 & $3501 g$ & $0.34 a$ & $8.75 i$ \\
\hline & 222222 & 10300 & $4131 b c$ & $0.34 a$ & $11.66 \mathrm{~h}$ \\
\hline & 250000 & 12820 & $4330 a$ & $0.32 b$ & $12.58 \mathrm{~h}$ \\
\hline & 333333 & 10530 & $4074 c$ & $0.30 c d$ & $24.02 e$ \\
\hline & 500000 & 13250 & $3113 j$ & $0.29 e f$ & $26.04 d e$ \\
\hline & 666666 & 10880 & $3038 j k$ & $0.27 \mathrm{gh}$ & $28.23 \mathrm{ed}$ \\
\hline & $L S D$ & $N S$ & 97 & $0.02^{\circ}$ & 2.6 \\
\hline & Hachalu & $11970 b$ & $3559 b$ & $0.29 b$ & $24.63 a$ \\
\hline \multirow[t]{5}{*}{ Variety mean } & Moti & $12260 a$ & $3578 b$ & $0.29 b$ & $21.85 b$ \\
\hline & Tumisa & $11710 c$ & $3698 a$ & $0.31 a$ & $18.54 c$ \\
\hline & $L S D$ & 238 & 39 & 0.01 & 1.06 \\
\hline & 166666 & $10450 e$ & $3371 d$ & $0.34 a$ & $9.86 d$ \\
\hline & 222222 & $10840 d$ & $4045 a$ & $0.32 b$ & $16.29 c$ \\
\hline
\end{tabular}




\begin{tabular}{llllll}
\hline Plant density mean & 250000 & $12250 b$ & $4202 a$ & $0.30 c$ & $16.45 c$ \\
& 333333 & $13120 b$ & $3920 b$ & $0.28 d$ & $27.49 b$ \\
& 500000 & $13820 a$ & $3090 e$ & $0.28 d$ & $28.68 b$ \\
& 666666 & $11380 c$ & $3032 f$ & $0.26 d$ & $31.28 a$ \\
& $L S D$ & 337 & 56 & 0.01 & 1.5 \\
& $C V(\%)$ & 12.9 & 11.6 & 12.5 & 7.6
\end{tabular}

Means followed by the different letters within columns are significantly different at $5 \%$ probability level, $\mathrm{NS}=$ not significant

\section{References}

Abdalla, M. M. F.; D.S. Darwish; A. A. Ali and E.A.A. El-Emam. 2000. Investigation on faba bean (Vicia faba. L.) Variability and clustering of faba bean Land Races. Egyptian Journal of Plant Breeding. 4: 257-272.

Abdalla A A. El Naim A M. Ahmed M F and Taha M B. 2015. Biological Yield and Harvest Index of Faba Bean (Vicia faba L.) as Affected by Different Agro-ecological Environments. World Journal of Agricultural Sciences. 3: 78-82.

Abd El-azeem K. Salem, Ehab H El-Harty, Megahed H. Ammar and Salem S. Alghamdi, 2014. Evaluation of Faba Bean (Vicia faba L.) Performance under Various Micronutrients Foliar Applications and Plant Spacing. Life Science Journal. 11(10):1298-1304.

Almaz M. Gezahegn, Kindie Tesfaye, J.J. Sharma and M.D. Belel. 2016. Determination of optimum plant density for faba bean (Vicia faba L.) on vertisols at Haramaya, Eastern Ethiopia, Cogent Food and Agriculture. 2: 1224485.

Al-Rifaee, Mohd Munir A. Turk, Abdel Rahman M. Tawaha. 2004. Effect of Seed Size and Plant Population Density on Yield and Yield Components of Local Faba Bean (Vicia faba L. Major). International journal of Agriculture and Biology. 6, No. 2,

Amanullah, A., M. Asif, K. Nawab, Z. Shah, M. Hassan, Z. Khan, K. Khalil, Z. Hussain, M. Tariq and H. Rahman, 2010. Impact of planting density and Pfertilizer source on the growth analysis of maize. Pakistan J. Bot. 42: 2349- 2357.

Ashenafi Mitiku and Mekuria Wolde. 2015. Effect of Faba Bean (Vicia faba L.) Varieties on Yield Attributes at Sinana and Agarfa Districts of Bale Zone, Southeastern Ethiopia. Jordan Journal of Biological Science. 8: $281-286$.

Asfaw Tilaye. 1985. Faba bean in Ethiopia. FABIS (Faba Bean Information Service) Newsletter, 12: 3-4.

Asfaw Tilaye, Geletu Bejiga and Alem Berhe. 1994. Role of cool season food legumes and their production constraints in Ethiopian agriculture. In: Asfaw Telaye, Geletu Bejiga, M. Saxen and M. Solh, (Eds.), Coolseason Legumes of Ethiopia. International center for Agricultural Research in Dry Areas, Addis Ababa, Ethiopia, 3-19.

Bakry, B.A, Elewa T.A., El-Karamany, M.F., Zeidan, M.S. and Tawfik, M.M. 2011. Effect of row spacing on yield and its components of some faba bean varieties under newly reclaimed sand soil condition. World Journal of Agricultural Sciences. 7(1): 68-72.

Biswas, D., Haque, M., Rahman, M. 2012. Influence of plant population density on growth and yield of two black gram varieties. Pakistan Journal Agronomy. 1(2-3): 83-85.

Bullock D., S. Khan and A. Rayburn, 1998. Soybean responses to narrow rows are largely due to enhanced early growth. Crop Sci. 38: 1011-1016

Dahmardeh, M., Ramroodi, M. 2010. Effect of plant density and cultivars on growth, yield and yield components of faba bean (Vicia faba L.). African Journal of Biotechnology. 9(50): 8643-8647.

Derogar and Mojaddam. 2014. Effect of plant density on grain yield and yield components in faba bean. International journal of plant, animal and environmental sciences. 4: 2231-4490.

Echarte L., S. Luque, H. Andrade, O. Sandras, A. Cirilo, E. Otegui and C. Vega, 2000. Response of maize kernel number to plant density in Argentinean hybrids released between 1965 and 1993. Field Crops Res. 68: 1-8.

FAOSTAT, Food and Agriculture Organization. 2009. Available online: http://faostat.fao.org/site/ 567/default.aspx\#ancor (accessed on 17 April 2015). United Nations field bean (Vicia faba L.var. minor).

Gebremeskel Y. Estifanos A and Melaku S. 2011. Effect of Selected Faba Bean (Vicia faba L.) Varietal Difference on Straw Dry Matter Yield, Chemical Composition and Nutritional Quality. Journal of the Dry lands 4: 333340.

Getachew Agegnehu and Rezene Fessehaie. 2006. Response of faba bean (Vicia faba L.) to phosphate fertilizer and weed control on Nitisols of Ethiopian highlands. Italian Journal of Agronomy. 2: 81-290.

Gomez, K. A., \& Gomez, A. A. 1984. Statistical procedures for agricultural research (2nd ed.). New York, NY: John Wily and Sons.

Hailu E, Getaneh G, Sefera T, Tadesse N, Bitew B. 2014. Faba Bean Gall; a New Threat for Faba Bean (Vicia faba) Production in Ethiopia. Advanced Crop Science Technology. 2: 144. 
Hashemi-dzefouli A. and J. Herbert, 1992. Intensifying plant density response of corn with artificial shade. Agron. J. 88: 82-84.

ICARDA, International Center for Agricultural Research in the Dry Areas. 2008. Impact of improved faba bean technologies in Africa. No. 2.

Khalil, S.K., A. Wahab, A. Rehman, F. Muhammad, S. Wahab, A.Z. Khan, M. Zubair, M.K. Shah, I.H. Khalil and R. Karadavut, U., C. Patla, Z. Kavurmac and Y. Bölek. 2010. Some grain yield parameters of multienvironmental trials in faba bean (Vicia faba L.) genotypes. International Journal of Agriculture and Biology. 12: $217-220$.

Khalil, S.K., A.W. Amanullah and A.Z. Khan. 2011. Variation in leaf traits, yield and yield components of faba bean in response to planting dates and densities. Egyptian Academic Journal of Biological Science. 2(1): 35 43.

Lemerle, D., R.D. Causens, L.S. Gill, S.J. Peltzer, M. Moerkerk, C.E. Murphy, D. Collins and B.R. Cullis. 2004. Reliability of higher seeding rates of wheat for increased competitiveness with weeds in low rainfall environment. Journal of Agricultural Science. 142: 395-409.

Lemerle, D., B. Verbeek and S. Diffey. 2006. Influence of field pea (Pisum sativum) density on grain yield and competitiveness with annual rye grass (Lolim rigidum) in South-Eastern Australia. Australian Journal of Experimental Agriculture. 46: 1465- 1472.

Leopold C. and E. Kreidemann, 1975. Plant growth and development. 2nd edition. McGraw Hill, New York.

Mahmoud E. Mekkei. 2014. Effect of intra-row spacing and seed size on yield and seed quality of faba bean (Vicia faba L.). International Journal of Agriculture and Crop Science. 7 (1 0), 665-670.

Malekmelki F, Majnoun HN, Alizadeh H. 2012. Effect of plant density on, yield and yield components of two lens cultivars. Journal of Agriculture and Biology. 22(4):33-40.

Mason, L., L. Mondart, R. Chaney, P. Martin and M. Milan, 1974. Corn forage as affected by plant population, nitrogen rate and hybrid on oliver soil. Bulletin of Agricultural Expermentation, Louisiana State University, LA, USA.

Mokhtar A. 2001. Response of yield and yield components of faba bean (Vicia faba L.) to increasing level of nitrogen and phosphorus under two levels of plant stand density. Annals Agricultural Science Ain Shams University. 46(1) : 143-154.

Mussa, J., and Gemechu, K. 2006. Vicia faba L. In M. Brink \& G. Belay (Eds.), PROTA 1: Cereals and pulses/ [CD-Rom]. PROTA: Wageningen.

Ogunlella B.,M. Amoruwa and O. Olongunde, 2005. Growth, yield components and micronutrient nutrition of field-grown maize (Zea mays L.) as affected by nitrogen fertilization and plant density. Nutr. Cycling Agroeco. 17 (2): 189-196.

Osman, A.A.M., S.O. Yagoub and O.A. Tut. 2010. Performance of faba beans (Vicia faba L.) cultivars grown in new agro ecological region of Sudan (Southern Sudan ). Australian Journal of Basic and Applied Science. 4(11): 5516-5521.

Park Y., K. Kang, U. Park and G. Moon, 1989. Effects of planting density and tiller removal on growth and yield of sweet corn hybrids. Korean J. Crop Sci. 34: 192-197.

Pesken, A., E. Pesken and C. Artı. 2006. Determination of plant characters and green pod yield of some faba bean (Vicia faba L.) populations. Journal of Faculty of Agriculture. OMU., 21(2): 225-230.

Rajcan I. and J Swanton, 2001. Understanding maize-weed competition: Resource competition, light quality and the whole plant. Field Crops Res. 71: 139-150.

Rehab A. M. Abd El-Rahman. 2014. Effect of plant population and distribution on yield and yield components of five faba bean genotypes. Journal of Plant Production, Mansoura University. 5 (11):1965 - 1972.

SAS, Staistical software. 2008. Statistical Analysis System. SAS institute version 9.20 Cary, NC, USA.

Sangoi L. and J. Salvador, 1996. Dry matter production and partitioning of maize hybrids and dwarf lines at four plant populations. Pesquisa Agropecuaria, Brasilia 33 (3): 1-15.

Sarah, A., E. Abusin, A.B. Hassan and E.E. Babiker. 2009. Nutritional evaluation of cooked faba bean (Vicia Faba L.) and white bean (Phaseolus Vulgaris L.) cultivars. Australian Journal of Basic and Applied Science. 3(3): 2484-2490.

Shad, K., Khalil, A., Wahab, A., Rehman, F. M., Wahab, S., Khan, A., Amin, R. 2010. Density and planting date inflence phenological development assimilate partitioning and dry matter production of faba bean. Pakistan Journal of Botany. 42, 3831-3838.

Shiferaw Mamo. 2008. Variety - mancozeb interactions of three varieties for the management of late blight across two locations - Awassa and Wolaita area. M. Sc. Thesis. University of Hawassa.

Singh D. and J. Chaudhary, 2008. Effect of plant population and fertilizer levels on yield and economics of popcorn. Indian J. Plant Sci. 78(4): 370-371.

Sitou, A., and Mywish, M. 2011. Global and regional trends in production, trade and consumption of food legume crops. Department of agricultural, food and resource economics Michigan State University, report submitted 
to SPIA, March 27.

Solomon Y. A. 2009. Integrated management of late blight (Phytophthora infestans) in potato (Solanum tuberosum) with emphasis on compost tea and Trichoderma harzianum. M.Sc Thesis. Submitted to School of Graduate Studies of the Haramaya University.

Tafere Mulualem, Tadesse Dessalegn, and Yigzaw Dessalegn. 2012. Participatory varietal selection of faba bean (Vicia faba L.) for yield and yield components in Dabat district, Ethiopia. Wudpecker Journal of Agricultural Research. 1(7), 270 - 274.

Tewodros Tesfaye Negash, Asfaw Azanaw, Getachew Tilahun, Kibersew Mulat and Samuel Sahile Woldemariam. 2015. Evaluation of Faba bean (Vicia faba L.) varieties against chocolate spot (Botrytis fabae) in North Gondar, Ethiopia. African Journal of Agricultural Research. 10(30), 2984-2988.

Tekle EK, Raghavaiah CV, Chavan A, Ibrahim H. 2015. Effect of faba bean (Vicia faba L.) genotypes, plant densities and phosphorus on productivity, nutrient uptake, soil fertility changes and economics in central high lands of Ethiopia. International Journal of Life Sciences. 3: 287-305.

Wakweya and Meleta. 2016. Effect of sowing method and seed rate on the growth, yield and yield components of faba bean (Vicia faba L.) under highland conditions of Bale, Southeastern Ethiopia. Research Journal of Agriculture and Environmental Management. 5(3). 086-094.

Yucel Derya Ozveren. 2013. Optimal intra-row spacing for production of local faba bean (Vicia faba L.Major) cultivars in the Mediterranean conditions. Pakistan Journal of Botany. 45(6):1933-1938. 